\title{
Lekarze polskiego pochodzenia na Ukrainie (XVIII-XX w.)
}

Pneumonol. Alergol. Pol. 2015; 83: 88-92

Po rozbiorach Polski (pod koniec XVIII wieku), do czasu powstania listopadowego (1830-1831), młodzież polska mogła kształcić się na polskich uniwersytetach oraz w Petersburgu. Po upadku powstania listopadowego, wszystkie polskie uniwersytety zostały zamknięte. Najdłużej działał Uniwersytet Wileński, który rozwiązano dopiero w 1841 roku. Nowe możliwości kształcenia się polskiej młodzieży stworzył powołany w Kijowie Uniwersytet św. Włodzimierza, do którego przeniosła się część kadry wykładowców Uniwersytetu Wileńskiego. Na Uniwersytecie Kijowskim wykładali między innymi: chemik, profesor Ignacy Fonberg (von Berg), uczeń Jędrzeja Śniadeckiego oraz fizjolog, profesor Karol Edward Miram, który był jednocześnie dziekanem Wydziału Lekarskiego w latach 1854-1862.

W latach 1834-1838 Polacy stanowili ponad połowę absolwentów Uniwersytetu Kijowskiego. Po powstaniu styczniowym (1863) ograniczono liczbę polskich studentów do $20 \%$ ogółu studiujących. Pomimo tych restrykcji, w drugiej połowie XIX wieku, ukraińskie uniwersytety ukończyło 535 polskich studentów. Uniwersytet Kijowski zajmował czwarte miejsce (po Wiedniu, Wrocławiu i Berlinie) wśród uczelni, które kształciły polskich lekarzy. Wielu z absolwentów zajmowało następnie stanowiska wykładowców na wydziałach lekarskich uniwersytetów ukraińskich.

$\mathrm{Na}$ Uniwersytecie Kijowskim nauczali jako starsi wykładowcy:

- Profesor Ludwik Górecki, który był w latach 1864-1884 kierownikiem Kliniki Dermatologicznej,

- Profesor Konrad Wagner - absolwent Uniwersytetu Kijowskiego, który był w latach
1897-1912 kierownikiem Kliniki Chorób Wewnętrznych,

- Profesor Aleksander Bylina — starszy wykładowca Kliniki Chorób Wewnętrznych w roku 1913,

- Profesor Antoni Wysokowicz - kierownik Katedry Anatomii Patologicznej w latach 1895-1912,

- Profesor Włodzimierz Lindeman z Katedry Patologii Ogólnej w latach 1901-1922,

- Profesor Antoni Trzesecki z Katedry Farmakologii.

Ponadto tytuł starszego wykładowcy na Uniwersytecie Kijowskim uzyskali: Edward Żebrowski — w Katedrze Chorób Wewnętrznych (1907), Jan Studziński - w Katedrze Fizjologii (1914), Ignacy Gofman - w Katedrze Chorób Wewnętrznych (1916) oraz Bronisław Kozłowski i Edward Bratkowski - w Klinice Chirurgii.

Na Uniwersytecie w Charkowie wykładali między innymi:

- Jan Stankiewicz, który był w latach 1850-1874 prosektorem i nauczycielem anatomii,

- Teodor Openchowski, w latach 1913-1919, profesor patologii i kierownik Kliniki Chorób Wewnętrznych,

- Bolesław Szarecki - starszy wykładowca i profesor Kliniki Chirurgii, który w stopniu generała Polskiej Armii walczył na frontach II wojny światowej a obecnie jest patronem Wojskowej Akademii Medycznej w Łodzi,

- Józef Sicjanko, w latach 1864-1884 wykładowca w dziedzinie elektroterapii,

- Włodzimierz Poraj-Koszyc, w latach 1884-1892 wykładowca w dziedzinie dermatologii i wenerologii.

Address for correspondence: prof. dr hab n. med. Janusz Kowalski, e-mail: jh.kowalski@wp.pl 
Wykładowcami na Uniwersytecie w Odessie byli Włodzimierz Werigo, który w latach 1894-1914 był profesorem Katedry Fizjologii oraz Emilian Bukojemski, pełniący obowiązki starszego wykładowcy.

Jednym z założycieli Uniwersytetu w Katerynosławiu (obecnie Dniepropietrowsk) i pierwszym dziekanem tej uczelni, był chirurg profesor Wincenty Tomaszewicz, który po drugiej wojnie światowej był organizatorem i profesorem Akademii Medycznej w Łodzi.

Na uniwersytecie w Dniepropietrowsku wykładał również Władysław Dzierżyński, student Uniwersytetu Moskiewskiego w latach 1913-1919, ordynator szpitala miejskiego w Charkowie i kierownik polikliniki neurologicznej Uniwersytetu w Charkowie. Po obronie pracy doktorskiej został profesorem i dziekanem (1920) w nowym Uniwersytecie w Dniepropietrowsku.

\section{Powroty do ojczyzny}

Po odzyskaniu przez Polskę niepodległości, podjęto się zorganizowania wydziałów lekarskich na Uniwersytetach w Warszawie, Wilnie, Krakowie, Poznaniu i w innych polskich miastach. Polscy lekarze po powrocie do Ojczyzny obejmowali pracę na kierowniczych stanowiskach nowo powołanych katedr.

Profesor Antoni Trzesecki zorganizował katedrę fizjologii Uniwersytetu w Poznaniu (1922-1924). Ernest Majdell, student a potem profesor Fizjologii Uniwersytetu Kijowskiego. Po powrocie do kraju wykładał fizjologię w latach 1920-1921 na Uniwersytecie im. St. Batorego w Wilnie, a w latach 1920-1930 na Uniwersytecie Jagiellońskim w Krakowie. Edward Żebrowski w latach 1927-1930 był kierownikiem I Kliniki Chorób Wewnętrznych Uniwersytetu Warszawskiego. Aleksander Januszkiewicz, asystent kijowskiej kliniki chorób wewnętrznych, po powrocie do Polski w 1921 roku został profesorem i kierownikiem II Kliniki Chorób Wewnętrznych Uniwersytetu im. Stefana Batorego w Wilnie.

Witold Goździkiewicz, absolwent Uniwersytetu Charkowskiego (1912), starszy wykładowca Uniwersytetu w Petersburgu, po powrocie do Polski został Profesorem Higieny i Bakteriologii na Uniwersytecie w Poznaniu i w Warszawie. Izabella Goździkiewicz, absolwentka Uniwersytetu Charkowskiego (1911) została profesorem Katedry Higieny w Akademii Medycznej w Szczecinie. Marcin Kacprzak, absolwent Uniwersytetu Charkowskiego (1915) został profesorem Katedry Higieny, i dziekanem Wydziału Lekarskiego w Warszawie. Juliusz Szymański, absolwent Uniwersytetu Kijowskiego w 1896, w latach 1908-1912 starszy wykładowca Kliniki Okulistycznej w Chicago, został profesorem Uniwersytetu Wileńskiego. Adam Wrzosek, absolwent Uniwersytetu Kijowskiego (1898) został profesorem ogólnej patologii i historii medycyny.

Zygmunt Radliński, absolwent Uniwersytetu Kijowskiego (1899) został profesorem Chirurgii Uniwersytetu Warszawskiego. Władysław Melanowski, absolwent Uniwersytetu Kijowskiego (1912) został profesorem Kliniki Okulistycznej Uniwersytetu Warszawskiego. Tadeusz Wąsowski został profesorem Kliniki Otolaryngologicznej Uniwersytetów w Wilnie i w Poznaniu. Stefan Baguński, absolwent Uniwersytetu Kijowskiego (1916), został profesorem Katedry Histologii Uniwersytetu w Łodzi. Jan Danielski został profesorem Katedry Higieny i Medycyny Pracy Akademii Medycznej w Lublinie. Włodzimierz Filiński, absolwent Uniwersytetu Kijowskiego (1916), został profesorem Kliniki Chorób Wewnętrznych Uniwersytetu Warszawskiego. Feliks Przesmycki, absolwent Uniwersytetu Kijowskiego (1915), został profesorem mikrobiologii i dyrektorem Państwowego Instytutu Higieny w Warszawie. Rajmund Barański, absolwent Uniwersytetu Kijowskiego (1917), został profesorem Kliniki Pediatrii Uniwersytetu Warszawskiego i ministrem zdrowia w PRL.

Stanisław Tarokan-Popowski, absolwent Uniwersytetu Kijowskiego (1917), został profesor Kliniki Pediatrycznej Akademii Medycznej w Łodzi. Adam Kwasowski, absolwent Uniwersytetu Kijowskiego (1919) został profesorem Kliniki Okulistycznej Uniwersytetu w Poznaniu. Marian Trawiński, absolwent Uniersytetu w Odessie (1916), został profesorem Kliniki Chirurgicznej Śląskiej Akademii Medycznej.

\section{Polscy lekarze i naukowcy wywodzący się z rodzin szlacheckich zamieszkałych na Ukrainie}

Piotr Zawadowski (1738-1812) od roku 1783 był dyrektorem Kliniki Medyczno-Chirurgicznej w Petersburgu, gdzie uczono tylko w języku niemieckim. Iwan Śmiłowski (1767-1808) studiował na Wydziale Lekarskim w Charkowie, a następnie w Medyczno-Chirurgicznej Szkole przy Szpitalu Admiralicji w St. Petersburgu. W 1798 uzyskał doktorat na Katedrze Patologii i Terapii na podstawie pracy „Elementy Medycyny Praktycznej”. Był znany jako autor publikacji o gruźlicy i jej leczeniu.

Kasjan Jagielski (1736-1774) ukończył szkołę medyczną Szpitala Admiralicji w St. Petersburgu. 
W 1775 roku obronił pracę doktorską „De Pasione Histerie" na Uniwersytecie w Lejdzie (Holandia). Następnie był profesorem fizjologii i patologii w szkole medycznej przy szpitalu Admiralicji w St. Petersburgu.

Wiktor Besser (1825-1890) urodzony w Krzemieńcu, na Wołyniu. W 1846 roku podjął studia medyczne w Moskwie, które ukończył z wyróżnieniem w roku 1851. Był znany jako specjalista wód mineralnych i ich zastosowania w praktyce medycznej. W 1855 roku obronił pracę doktorską „O efektach terapeutycznych wód mineralnych”. Od 1860 roku w ciągu 25 lat był profesorem katedry patologii , diagnostyki i ogólnej terapii w medyczno-chirurgicznej Akademii w St. Petersburgu. Był członkiem rady redakcyjnej „Przeglądu Wojskowo-Medycznego". Zmarł w St. Petersburgu.

Teofil Wdowiakowski (1844-1916) urodził się na Podolu w Proskurowie w polskiej rodzinie. W 1858 roku ukończył wydział lekarski Uniwersytetu w Kijowie. Jego aktywność zawodowa była związana z szpitalem miejskim w Odessie, gdzie od 1889 roku był głównym lekarzem. Pracował też w Paryżu w Klinice Urologicznej u Prof. Civial ( Hopital du Midi). Był znanym urologiem, wenerologiem i świetnym operatorem. Osobiście wykonał około tysiąca zabiegów za pomocą uretrotomii. Był autorem około 20 publikacji w zakresie urologii.

Antoni Wysokowicz (1854-1912) urodził się w miejscowości Gąsin na Podolu w rodzinie weterynarzy. Od 1871 roku był studentem Wydziału Lekarskiego Uniwersytetu w Charkowie. Od trzeciego roku studiów interesował się anatomią patologiczną. W 1876 roku był lekarzem wojskowym na Kaukazie. W trzy lata później obronił pracę doktorską pt. „O zmianach w naczyniach krwionośnych u chorych na kiłę". Od roku 1868 był starszym wykładowcą Katedry Patologii Ogólnej, a od roku 1877 był prosektorem w Katedrze Anatomii Patologicznej na Uniwersytecie w Charkowie. W 1889 roku kierował stacją bakteriologiczną w Charkowie i w Instytucie Pasteura w Paryżu. W latach 1895-1912 był profesorem i kierownikiem Katedry Anatomii Patologicznej na Wydziale Lekarskim w Kijowie. Założył także szkołę mikrobiologiczną w Kijowie i organizował walkę $\mathrm{z}$ epidemią cholery. Zmarł w Kijowie.

Włodzimierz Podwysocki (1857-1913) wybitny patolog i bakteriolog - urodził się w Czernihowie w polskiej rodzinie szlacheckiej. Ukończył studia na Uniwersytecie w Kijowie, a potem podjął obowiązki profesora katedry patologii ogólnej. Był organizatorem i pierwszym dziekanem Wydziału Lekarskiego w Odessie (1900-1905) także autorem podręcznika pt. „Basis for general and experimental pathology” 1891). W 1896 roku wysunął hipotezę, że nadnercza mogą odgrywać istotną role w obronie organizmu przeciwko toksycznym produktom metabolicznym.

Ludwik Górecki (1826-1885) urodził się na Wołyniu, w rodzinie szlacheckiej. W 1848 roku ukończył Wydział Lekarski w Kijowie. W 1855 obronił pracę doktorską pt. „De sputis in pneumonia acuta primaria". W latach 1855-1975 był lekarzem Collegium Księżnej Levaszkowej w Kijowie. W latach 1864-1880 kierował Kliniką Dermatologiczną na Uniwersytecie w Kijowie. Był również ordynatorem w kijowskim szpitalu wojskowym. Jednocześnie w tych latach uznawany za najlepszego znawcę dermatologii i wenerologii na Uniwersytecie w Kijowie.

Mikołaj Zaleski (1854-1895) urodził się w rodzinie szlacheckiej. W 1860 roku ukończył z wyróżnieniem wydział lekarski Uniwersytetu w Kijowie. W 1864 roku w Akademii Medyczno-Chirurgicznej w Petersburgu obronił pracę doktorską pt. „, Zaburzenia w mocznicy wskutek uszkodzenia nerek”. Od 1868 roku był profesorem toksykologii w Katedrze Medycyny Sądowej Uniwersytetu w Charkowie, a od 1883 roku profesorem Katedry Farmakologii. Uznawany jest za wybitnego ukraińskiego farmakologa i autorytet w zakresie medycyny sądowej.

Franciszek Ziębicki (1849-1913) w roku 1876 ukończył wydział lekarski Uniwersytetu w Kijowie. W 1879 roku pełnił funkcje lekarza wojskowego w czasie wojny rosyjsko-tureckiej. W Wojskowej Akademii Medycznej (w 1886 roku obronił pracę doktorską dotyczącą metody chemicznego oczyszczania wody pitnej. Brał także udział w walce z epidemią cholery.

Franciszek Błoński (1867-1910) studiował na wydziale lekarskim w Warszawie. W roku 1891 wyjechał na Ukrainę i pracował w Spiczyńcy koło Kijowa gdzie pełnił obowiązki lekarza cukrowni. Łączył praktykę medyczną ze studiami w zakresie botaniki. Opracował systematykę kwiatów i mchów na Ukrainie i w Polsce. Był autorem ponad 40 publikacji w języku polskim. Wniósł kilka obserwacji botanicznych o jemiole oraz grzybach jadalnych i trujących na Ukrainie (1893-1894).

Kajetan Czesław Wróblewski (1834-1901) absolwent wydziału lekarskiego Uniwersytetu w Kijowie. Poświęcił się badaniom higieny zwłaszcza u dzieci. Opublikował obserwacje dotyczące znaczenia higieny w środowiskach społecznych. 


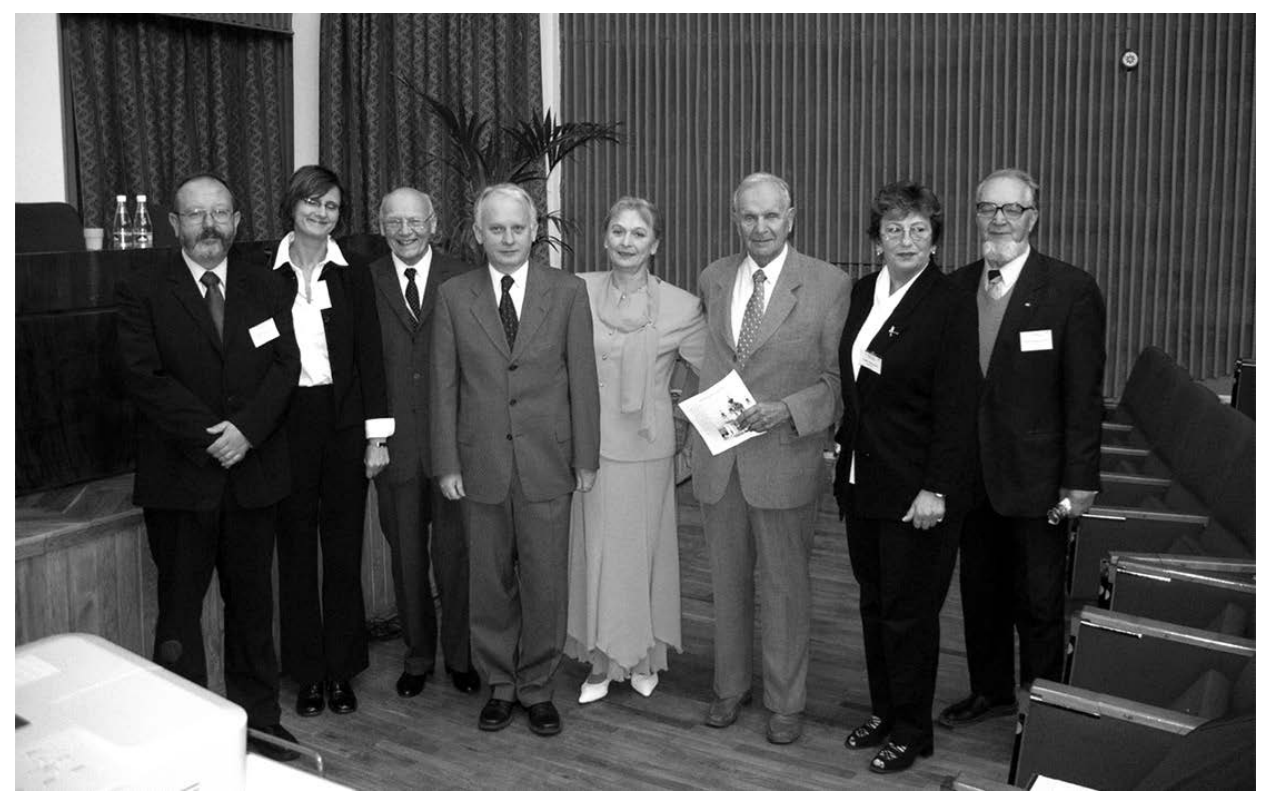

Rycina 1. Druga Konferencja Naukowa Polsko-Ukraińskiej Grupy Roboczej Polskiego Towarzystwa Chorób Płuc w Kijowie, dnia 7 paździrnika 2005 roku. Miejsce Konferencji: Kijów, Instytut Fizjologii im. Bohomolca. Organizatorzy konferencji (od lewej strony):

Prof. Kozielski (Uniwersytet Medyczny w Zabrzu), Prof. Joanna Chorostowska-Wynimko (dyrektor naukowy Instytutu Chorób Płuc w Warszawie), Prof. Janusz Kowalski (Instytut Chorób Płuc w Warszawie), Ambasador RP w Kijowie Jerzy Kluczkowski, Prof., Tatiana Serebrovska (Instytut Fizjologii w Kijowie), Prof. Akademik Jerzy Platon Kostyuk (dyrektor Instytutu Fizjologii w Kijowie), Prof. Zofia Zwolska (Zakład Mikrobiologii Instytut Chorób Płuc w Warszawie), Prof. Wadim Berezovski (Instytutu Fizjologii w Kijowie)

\section{Instytut Fizjologii im. Aleksandra Bohomolca w Kijowie}

Na wzgórzu Klonowskim w Kijowie mieści się Instytut Fizjologii im. Bohomolca Ukraińskiej Akademii Nauk. Akademik Aleksander Bohomolec (1881-1046) wywodził się z polskiej rodziny szlacheckiej, zamieszkałej na Ukrainie od XV wieku. Studia ukończył na Uniwersytecie w Odessie (1906), a potem pracował w Kijowie od 1931 do 1946 roku. To on właśnie zorganizował Instytut Klinicznej Fizjologii, a następnie Instytut Patologii Eksperymentalnej. W latach 1930-1946 był prezydentem Ukraińskiej Akademii Nauk. W swoich badaniach zajmował się strukturą i funkcją tkanki łącznej, co stało się podstawą nauki o chorobach z nią związanych. Był autorem koncepcji starzenia się, rozumianej jako zmiany fizykochemiczne zachodzące w komórkach i tkankach. Wyniki badań dotyczących gerontologii opisał w książce pt. Prolongation of Live (1940), tłumaczonej na wiele języków.

Wśród kadry pracowników naukowych Instytutu Fizjologii im. Aleksandra Bohomolca jest wiele osób z polskimi korzeniami. Profesor Nikita Mańkowski, obecnie stuletni senior, wywodzi się ze starej polskiej rodziny szlacheckiej , która zamieszkiwała na Ukrainie od 1692 roku. W dowód wielu zasług rodzina otrzymała ziemię i została wyróżniona herbem „szczerbiec”. Profesor Mańkowski jest lekarzem, twórcą neuro-geriatrii i laureatem państwowej nagrody ukraińskiej. Profesor Irina Mańkowska, córka prof. Nikity Mańkowskiego (ur. W 1941 r.) jest także długoletnim pracownikiem Instytutu A. Bohomolca, gdzie pełni funkcję kierownika Zakładu Stanów Hipoksycznych. Głównym tematem Zakładu jest badanie podstawowych mechanizmów, odpowiedzialnych za adaptację do hipoksji ustrojowej.

Profesor Wadim Berezovski (ur. W 1932 r.), kierownik Samodzielnego Zakładu Klinicznej Patofizjologii Instytutu A. Bohomolca jest także przedstawicielem starej polskiej rodziny arystokratycznej, zamieszkałej na Ukrainie od XII wieku. Głównym kierunkiem badań tego Zakładu są choroby cywilizacyjne i metody zapobiegania im.

Interesujące studia dotyczące powstawania i eliminacji znamion naczyniowych w skórze prowadzi w Instytucie Fizjologii profesor Olga Bohomolec (ur. W 1966 r.), córka prof. Berezovskiego i prawnuczka prof. Aleksandra Bohomolca, założyciela tej placówki naukowej. Prof. Olga Bohomolec jest uznanym lekarzem w Instytucie Dermatologii Uniwersytetu Medycznego w Kijowie. 


\section{Uniwersytet Medyczny w Kijowie}

Profesor Antoni Święcicki jest prorektorem Uniwersytetu Medycznego w Kijowie oraz kierownikiem Kliniki Chorób Wewnętrznych. Jest specjalistą w zakresie chorób płuc i gastrologii. Profesor Święcicki to znakomity dydaktyk i nauczyciel akademicki, a także organizator życia naukowego na Uniwersytecie. Dużo uwagi przywiązuje do współpracy sąsiedzkiej z instytucjami naukowymi w Polsce. W 2013 roku uzyskał tytuł doktora honorowego Warszawskiego Uniwersytetu Medycznego.

Jak wykazano w tym przeglądzie, wielu lekarzy polskiego pochodzenia kształciło się i pracowało w ośrodkach medycznych na Ukrainie. Wielu z nich po powrocie do odrodzonej Polski przyczyniło się do odbudowy wyższego szkolnictwa medycznego po roku 1918.

Wypada tu nadmienić, że 10 lat temu powstała z inicjatywy Polskiego Towarzystwa Chorób Płuc (PTChP) grupa polsko-ukraińska, obejmu- jąca lekarzy chorób płuc i innych specjalności. W ciągu tych lat odbywały się coroczne spotkania naukowe zarówno pneumonologów, jak i fizjopatologów w Polsce i na Ukrainie (ryc. 1).

Owocem tej współpracy jest między innymi rosyjskie wydanie książki Ocena czynności płuc $w$ chorobach układu oddechowego pod redakcją Janusza Kowalskiego, Antoniego Koziorowskiego i Leszka Radwana. Książka ta przetłumaczona przez dr Eugenię Kolesnikową została wydana przez Instytut Gruźlicy i Chorób Płuc i wydawnictwo Borgis (Warszawa 2008).

\section{Przy opracowaniu niniejszego tekstu korzystano z następujących źródel:}

1. Ganitkewicz Y., Contribution of Ukrainian Physicians at World Medicine. Ukr. Med. J. 2009; 4; 72: 110-115.

2. Grando A. The travel to last of medicine. Wyd. Triumph, Kijów 1995.

3. Medicine in Ukraine. Outstanding Physicians. End of XVIIfirst half of XIX centuries. Kijów 1997.

4. Medicine in Ukraine, Bibliographical Dictionary. Kijów 1997.

5. Uliyash P. The issues of the transfer to Ukraine of Polish experience of high medical education (XV-XVII centures). Ukrainian Medical Journal 2007; 61: 135-138. 